\title{
Identification of novel peptides from goat milk casein that ameliorate high-glucose-induced insulin resistance in HepG2 cells
}

\author{
H. Gong, J. Gao, Y. Wang, Q. W. Luo, K. R. Guo, F. Z. Ren, and X. Y. Mao* \\ Beijing Advanced Innovation Center for Food Nutrition and Human Health, College of Food Science and Nutritional Engineering, \\ Key Laboratory of Functional Dairy, China Agricultural University, Beijing 100083, P. R. China
}

\begin{abstract}
In this study, we investigated the effect of goat milk casein hydrolysates on glucose consumption rate, intracellular glycogen concentration, and mRNA expression of gluconeogenesis-related genes, including phosphoenolpyruvate carboxykinase 1 ( $P C K 1)$ and glucose6-phosphatase catalytic subunit $(G 6 P C)$, in insulinresistant HepG2 cells. From the obtained hydrolysates, we also purified and characterized novel peptides that ameliorated high-glucose-induced insulin resistance in HepG2 cells. The 3-h hydrolysate caused the highest glucose consumption rate in insulin-resistant HepG2 cells. It also showed positive effects on promoting intracellular glycogenesis and reducing mRNA expression of $P C K 1$ and $G 6 P C$. We separated the obtained hydrolysates into 3 fractions (F1, F2, and F3) by gel filtration chromatography; we further purified F1 using reversedphase HPLC and identified peptides using liquid chromatography-tandem mass spectrometry. The bioactive peptides identified were SDIPNPIGSE $\left(\alpha_{\mathrm{S} 1}\right.$-casein, f195-204), NPWDQVKR ( $\alpha_{\mathrm{S}_{2}}$-casein, f123-130), SLSSSEESITH ( $\beta$-casein, f30-40), and QEPVLGPVRGPFP ( $\beta$-casein, f207-219). Our findings indicated that specific bioactive peptides from goat milk casein hydrolysates ameliorated insulin resistance in HepG2 cells that had been treated with high glucose. This is a first step toward determining whether goat milk casein hydrolysates can be used as food ingredients to ameliorate insulin resistance.
\end{abstract}

Key words: goat milk casein, insulin resistance, HepG2 cells, peptide sequence

\section{INTRODUCTION}

Approximately 400 million people around the world live with type 2 diabetes mellitus, a chronic disease that causes almost 5 million deaths each year. It is expected

Received August 28, 2019.

Accepted February 4, 2020

*Corresponding author: maoxueying@cau.edu.cn that the number of people with type 2 diabetes will reach 640 million by 2040 (Matboli et al., 2018; Cheng et al., 2019). Complications of diabetes include retinopathy, nephropathy, and cardiovascular disease, and they pose serious risks for people with type 2 diabetes (Parsamanesh et al., 2018).

The liver, which is the major target organ for insulin action, controls glucose metabolism by regulating glucose storage (glycogenesis) and glucose output (gluconeogenesis; Nocito et al., 2015; Yamaguchi et al., 2015). Under normal circumstances, insulin binds to receptors in the liver to elevate glucose consumption and glycogenesis to maintain blood glucose levels (Kubota et al., 2016). However, when insulin sensitivity is impaired, insulin resistance occurs and ultimately leads to a disruption of energy homeostasis and to type 2 diabetes (Rungapamestry et al., 2012; Milburn and Lawton, 2013). Improving insulin resistance is an effective method of preventing and treating type 2 diabetes. As well, when gluconeogenesis is regulated abnormally, glucose production is increased, contributing to hyperglycemia (Kim et al., 2014; Sharabi et al., 2015). Phosphoenolpyruvate carboxykinase 1 (encoded by PCK1) and glucose-6-phosphatase catalytic subunit (encoded by $G 6 P C$ ) are key enzymes that regulate gluconeogenesis (Ren et al., 2018). The expression of PCK1 and $G 6 P C$ was increased in a rodent model of diet-induced obesity and insulin resistance (Meng et al., 2013).

Various drugs are available for treatment of type 2 diabetes. However, some of these, known as thiazolidinediones and metformin, cause adverse effects such as weight gain, hypoglycemia, and gastrointestinal damage (Dujic et al., 2016). Safer substances from natural dietary sources are needed for the management and prevention of diabetes. Bioactive peptides derived from food proteins - such as antioxidant peptides from eggs, antimicrobial peptides from legumes, and antihypertensive peptides from millet - have potential health benefits (Gressent et al., 2011; Nimalaratne et al., 2015; Chen et al., 2017). Milk-derived peptides obtained from hydrolysis or fermentation possess antihypertensive, antioxidant, and antimicrobial activity (Kume et al., 
2014; Jafar et al., 2018; Zanutto-Elgui et al., 2019). Antidiabetic and hypoglycemic activity have also been reported in milk-derived peptides. These peptides have been shown to inhibit dipeptidyl peptidase 4 (DPP4), an enzyme that can lead to type 2 diabetes (JuilleratJeanneret, 2014). The DPP4 enzyme cleaves incretins such as glucagon-like peptide 1 and glucose inhibitory polypeptide, hormones released from the gut into the bloodstream after meal ingestion to stimulate insulin secretion and maintain whole-body glucose homeostasis (Kim and Egan, 2008). The peptides NLEIILR ( $\beta$-LG, f71-77) and TQMVDEEIMEKFR ( $\beta$-LG, f143-155) from mare whey protein hydrolysates have shown DPP4 inhibition activity and potential for the management of type 2 diabetes (Song et al., 2017a). Some DPP4 inhibitory peptides from bovine milk, such as LPQNIPPL $(\beta-\mathrm{CN}, \mathrm{f} 70-77)$ and FLQP $(\beta-\mathrm{CN}, \mathrm{f} 87-90)$, have been shown to prevent type 2 diabetes (Uenishi et al., 2012; Nongonierma et al., 2017).

Recently, interest has been growing in goat milk because of its nutritional value for human health. The AA composition of goat milk is more similar to that of human breast milk than to that of bovine milk, and it can be absorbed and digested easily, especially by newborns (Carver, 2003; Inglingstad et al., 2010). Goat milk has high levels of essential AA, including Thr, Ile, Lys, Cys, Tyr, and Val (Haenlein, 2004). As well, bioactive peptides with antioxidant, antibacterial, and antithrombotic activity have been found in goat milk casein hydrolysates (Atanasova and Ivanova, 2010; Espejo-Carpio et al., 2013). However, research on identifying peptides from goat milk casein to ameliorate insulin resistance is limited.

The aim of this study was to evaluate the effects of goat milk casein hydrolysates on glucose metabolism in insulin-resistant HepG2 cells to develop novel functional ingredients for the prevention and treatment of insulin resistance. We investigated the insulin-sensitizing effects of goat milk casein hydrolysates using HepG2 cells with high-glucose-induced insulin resistance. We also purified and identified peptides that ameliorated insulin resistance.

\section{MATERIALS AND METHODS}

\section{Materials and Chemicals}

We obtained skim goat milk powder from Huayile Animal Husbandry Technology Co., Ltd. (Inner Mongolia, China). We obtained Flavourzyme (EC 3.4.11.1, 500 leucine aminopeptidase units per gram) from Novozymes (Franklinton, NC). We purchased a glucose assay kit and a glycogen assay kit from Nanjing Jiancheng Bioengineering Institute (Nanjing, China). Trifluoro- acetic acid, acetonitrile, and formic acid (HPLC grade) were supplied by Fisher Co. (Fair Lawn, NJ). We obtained TRIzol reagent from Tiangen Biotech (Beijing, China) and purchased a cDNA synthesis kit from ABM Inc. (Richmond, BC, Canada).

\section{Preparation and Hydrolysis of Goat Milk Casein}

The dispersion of the skim milk powder was adjusted to $\mathrm{pH} 4.4$ and then centrifuged at $1,610 \times g$ for 10 min at $4^{\circ} \mathrm{C}$ to precipitate the casein ( $\mathrm{Li}$ et al., 2013). The supernatant was removed and the precipitate lyophilized to obtain the freeze-dried casein powder. Then, the lyophilized goat milk casein was dissolved in distilled water $(5 \%$, wt/vol). Finally, the substrate was hydrolyzed with Flavourzyme $(5 \%$, enzyme:substrate ratio) at $\mathrm{pH} 7.0$ and $50^{\circ} \mathrm{C}$. We collected goat milk casein hydrolysates at $0.25,0.50,0.75,1,2,3,4$, and $5 \mathrm{~h}$. The enzymatic hydrolysates were heated at $90^{\circ} \mathrm{C}$ for 10 min and centrifuged at $10,000 \times g$ for 20 min at $4^{\circ} \mathrm{C}$. Finally, the supernatant was lyophilized for further analysis.

\section{Determination of Degree of Hydrolysis}

The degree of hydrolysis (DH) was determined using a trinitrobenzenesulfonic acid solution assay (Ma et al., 2014). The goat milk casein hydrolysates were mixed with $1 \%$ SDS and then $0.125 \mathrm{~mL}$ of each hydrolysate sample was mixed with sodium phosphate buffer (0.2125 M, pH 8.2) and $1 \mathrm{~mL}$ of trinitrobenzenesulfonic acid solution in water $(0.1 \%, \mathrm{vol} / \mathrm{vol})$. The samples were incubated at $50^{\circ} \mathrm{C}$ for $1 \mathrm{~h}$ and the reaction stopped by adding $2.0 \mathrm{~mL}$ of $0.1 \mathrm{M} \mathrm{HCl}$. Samples were kept at room temperature for $30 \mathrm{~min}$ and then the absorbance value was measured at $340 \mathrm{~nm}$ using a UV-visible spectrophotometer UV-2600 (UNIC, Shanghai, China). We used 0 to $5.0 \mathrm{mmol} / \mathrm{L}$ leucine as a standard, and treated the blank in the same way. We calculated DH using the following equation:

$$
\mathrm{DH}(\%)=\left(h / h_{t o t}\right) \times 100 \% \text {, }
$$

where $h$ was the number of disrupted peptide bonds $\left(\mathrm{mEq} / \mathrm{g}\right.$ of protein), and $h_{t o t}$ was the number of total peptide bonds per unit of weight $(8.2 \mathrm{mEq} / \mathrm{g}$ of protein).

\section{Cell Culture and Treatments}

The HepG2 cells were purchased from Peking Union Medical College Hospital (Beijing, China) and cultured in Minimum Essential Medium (MEM) with 10\% fetal 
bovine serum, $1 \%$ nonessential amino acids, and $100 \mathrm{U} /$ $\mathrm{mL}$ penicillin-100 $\mu \mathrm{g} / \mathrm{mL}$ streptomycin (Thermo Fisher Gibco, Waltham, MA). The cells $\left(1 \times 10^{5}\right.$ cells $\left./ \mathrm{mL}\right)$ were incubated at $37^{\circ} \mathrm{C}$ in a humidified atmosphere that contained $5 \% \mathrm{CO}_{2}$. The cells were treated with $5.5 \mathrm{~m} M$ glucose $(5 \%, \mathrm{vol} / \mathrm{vol})$ to represent normoglycemia for $24 \mathrm{~h}$, followed by $100 \mathrm{n} M$ insulin (5\%, vol/ vol) stimulation for $10 \mathrm{~min}$. We established a model of high-glucose-induced insulin resistance as described previously (Cordero-Herrera et al., 2014; Song et al., 2017b). Briefly, we cultured the HepG2 cells in medium supplemented with $30 \mathrm{mM}(5 \%$, vol/vol) glucose to represent hyperglycemia with or without goat milk casein hydrolysates for $24 \mathrm{~h}$, followed by $100 \mathrm{n} M$ insulin (5\%, $\mathrm{vol} / \mathrm{vol}$ ) stimulation for $10 \mathrm{~min}$, and then harvested them.

\section{Cell Viability Analysis}

We measured cell viability using a 3-(4,5-dimethylthiazol-2-yl)-2,5-diphenyl tetrazolium (MTT) assay, as reported previously ( $\mathrm{Li}$ et al., 2017b). Briefly, cells were seeded into 96 -well plates at a density of $5 \times 10^{4}$ cells per well for $12 \mathrm{~h}$ and incubated with normal (5.5 $\mathrm{m} M)$ or high $(30 \mathrm{~m} M)$ glucose in the presence of various concentrations of goat milk hydrolysates $(0,0.25$, 0.50 , and $1.00 \mathrm{mg} / \mathrm{mL}$ ) for $24 \mathrm{~h}$. Then, $20 \mu \mathrm{L}$ of MTT reagent $(5 \mathrm{mg} / \mathrm{mL})$ was mixed with the cell cultures for $4 \mathrm{~h}$ at $37^{\circ} \mathrm{C}$. After that, the formed blue formazan crystals were dissolved with $200 \mu \mathrm{L}$ of dimethyl sulfoxide. Absorbance was read at $570 \mathrm{~nm}$ by using a microplate reader (Bio-Rad, Hercules, CA). Cell viability was expressed as a percentage of the optical density relative to the optical density of the control group without $30 \mathrm{mM}$ $(5 \%, \mathrm{vol} / \mathrm{vol})$ glucose and goat milk hydrolysates. We also investigated the effects on cell viability of 3 fractions (F1, F2, and F3) separated by gel filtration on a Sephadex G-25 column $(2.5 \times 70 \mathrm{~cm}$; GE Healthcare BioSciences, Beijing, China).

\section{Glucose Consumption Rate}

We determined the glucose consumption rate as reported previously, with slight modifications (Chen et al., 2016; Li et al., 2017a; Gowd et al., 2018). The HepG2 cells were seeded into 96 -well plates at $1 \times 10^{5}$ cells/ $\mathrm{mL}$ for $24 \mathrm{~h}$; blank wells contained only medium. Then, $30 \mathrm{~m} M$ glucose $(5 \%, \mathrm{vol} / \mathrm{vol})$ was added to the medium in the absence (model group) or presence (treatment group) of goat milk casein hydrolysates, followed by incubation for $24 \mathrm{~h}$ and $100 \mathrm{n} M$ insulin (5\%, vol/vol) stimulation for $10 \mathrm{~min}$; PBS was used as a control. Glucose concentration was measured using the glucose oxidase-peroxidase method with an assay kit based on a previous reference method (Wang et al., 2018). Briefly, the medium supernatant was collected and mixed with the glucose reagent at $1: 100(\mathrm{vol} / \mathrm{vol})$; the standard glucose solution was mixed with the glucose reagent at $1: 100$ ( $\mathrm{vol} / \mathrm{vol}$ ) as the calibration tube; distilled water was used as the control tube. After incubating for 10 min at $37^{\circ} \mathrm{C}$, the absorbance value at $505 \mathrm{~nm}$ was measured and glucose concentration calculated using the following equation:

$$
\begin{aligned}
& \text { Glucose concentration }=\text { optical density }(\text { sample }) / \\
& \text { optical density }(\text { standard glucose solution }) \times 5.55 \text {, }
\end{aligned}
$$

where the concentration of the standard glucose solution was $5.55 \mathrm{mM}$. We calculated the glucose consumption rate using the following equation:

Glucose consumption rate $=[$ (glucose concentration

in blank wells - glucose concentration of cell plated wells)/glucose concentrations in blank wells] $\times 100 \%$.

\section{Analysis of Intracellular Glycogen Concentration}

We determined intracellular glycogen concentration as reported previously (Song et al., 2017b). Cells $(1 \times$ $10^{6}$ cells $/ \mathrm{mL}$ ) were homogenized with $200 \mu \mathrm{L}$ of distilled water on ice. Then, the homogenates were boiled for $10 \mathrm{~min}$ to inactivate the endogenous enzymes in the sample and centrifuged at $18,000 \times g$ for $10 \mathrm{~min}$ to remove the insoluble material. Then, the supernatants were assayed for intracellular glycogen concentration. Briefly, $10 \mu \mathrm{L}$ of sample was added to 96 -well plates and the volume adjusted to $50 \mu \mathrm{L}$ with hydrolysis buffer. The glycogen standard was diluted to different concentrations with hydrolysis buffer to plot the standard curve. Then, $2 \mu \mathrm{L}$ of hydrolysis enzyme mix was added to the standards and samples, which were incubated at room temperature for $30 \mathrm{~min}$. Then, $50 \mu \mathrm{L}$ of the reaction mix, which included $46 \mu \mathrm{L}$ development buffer, $2 \mu \mathrm{L}$ development enzyme mix, and $2 \mu \mathrm{L}$ oxired probe, was mixed with the standards or samples. The mixture was incubated at room temperature for $30 \mathrm{~min}$ in the dark and absorbance value was monitored at 420 $\mathrm{nm}$ with a microplate reader (Bio-Rad). The glycogen concentration of the samples was calculated using the following equation and expressed as a percentage of the control group [without $30 \mathrm{~m} M(5 \%, \mathrm{vol} / \mathrm{vol})$ glucose and goat milk hydrolysates]:

Glycogen concentration of samples $(C)=$

$$
B / V(\mu \mathrm{g} / \mu \mathrm{L}),
$$


where $B$ was the amount of glycogen from a standard curve $(\mu \mathrm{g}), V$ was the sample volume added to the reaction well $(\mu \mathrm{L})$, and the volume of samples added in this experiment was $10 \mu \mathrm{L}$.

\section{Determination of mRNA Expression of PCK1 and G6PC by Reverse Transcription Quantitative PCR}

We evaluated the mRNA expression of $P C K 1$ and $G 6 P C$ as described previously (Bao et al., 2015). Total RNA was extracted from the HepG2 cells using TRIzol reagent, and the concentration and quality of the RNA were evaluated using a Multiskan Go microplate spectrophotometer (Thermo Fisher Scientific). First-strand cDNA was synthesized from $2 \mu \mathrm{g}$ of total RNA in a $20-\mu \mathrm{L}$ reaction volume using an EasyScript Plus cDNA Synthesis Kit (ABM) according to the manufacturer's instructions in a C1000 Thermal Cycler (Bio-Rad; Gao et al., 2019). Then, mRNA expression was quantified with $1 \mu \mathrm{L}$ of cDNA templates, $0.2 \mu \mathrm{L}$ of forward primer, $0.2 \mu \mathrm{L}$ of reverse primer, $10 \mu \mathrm{L}$ of YBR Green qPCR Master mix (Takara, Otsu, Shiga, Japan), and $8.6 \mu \mathrm{L}$ of distilled, deionized $\mathrm{H}_{2} \mathrm{O}$ using a Techne Quantica realtime PCR detection system (Techne, Stone, Staffordshire, UK). The thermal profile for reverse transcription quantitative PCR was as follows: initial denaturation at $95^{\circ} \mathrm{C}$ for $180 \mathrm{~s}$, denaturation at $95^{\circ} \mathrm{C}$ for $5 \mathrm{~s}$ (40 cycles), annealing at $60^{\circ} \mathrm{C}$ for $30 \mathrm{~s}$, and extension at $72^{\circ} \mathrm{C}$ for 30 s. The mRNA expression levels of PCK1 and G6PC were determined with glyceraldehyde-3-phosphate dehydrogenase $(G A P D H)$ as a housekeeping gene. Data are presented as the fold change of each sample group relative to the control group [without $30 \mathrm{mM}$ (5\%, vol/ vol) glucose and goat milk hydrolysates], and we used the $2^{-\Delta \Delta \mathrm{Ct}}$ method to quantify gene expression (Pfaffl, 2001).

Primer sequences were: PCK1 (forward 5'-CTTTGGAGGCCGTAGACCTG-3'; reverse 5'-GCCTTTATGTTCTGCAGCCG-3'); G6PC (forward 5'-GTGAATTACCAAGACTCCCAG-3'; reverse 5'-GCCCATGGCATGGCCAGAGGG-3'); and GAPDH (forward 5'-CAACGGATTTGGTCGTATTGG-3'; reverse 5'-GCAACAATATCCACTTTACCAGAGTTAA-3').

\section{Purification of Goat Milk Casein Hydrolysate by Gel Filtration Chromatography and Reversed-Phase HPLC}

Goat milk casein hydrolysates with the highest glucose consumption rate in insulin-resistant HepG2 cells were separated by gel filtration on a Sephadex
G-25 column equilibrated with distilled water (Zhang et al., 2011; Samarakoon et al., 2013). Each 3.5-mL fraction was collected at a flow rate of $0.7 \mathrm{~mL} / \mathrm{min}$. We monitored absorbance at $220 \mathrm{~nm}$ to identify peptide fractions. All fractions were collected and lyophilized for future analysis.

The fraction with the highest glucose consumption rate was purified by reversed-phase HPLC according to Zhang et al. (2015), with minor modifications. Briefly, the samples were separated on a Kromasil C18 (4.6 $\times 250 \mathrm{~mm}$; Akzo Nobel, Bohus, Sweden) at a rate of $1 \mathrm{~mL} / \mathrm{min}$. Solvent A consisted of $0.1 \%$ trifluoroacetic acid ( $\mathrm{vol} / \mathrm{vol}$ ) in water, and solvent B consisted of $0.1 \%$ trifluoroacetic acid (vol/vol) in acetonitrile. The linear gradient was 10 to $90 \%$ solvent B for $30 \mathrm{~min}$. To obtain the peaks of elution, we used a UV detector at $220 \mathrm{~nm}$.

\section{Determination of Peptide Sequences by Liquid Chromatography-Tandem Mass Spectrometry}

We evaluated the peptide sequences of goat milk casein hydrolysates using liquid chromatography-tandem mass spectrometry (LC-MS/MS) with a nanoAcquity nano HPLC system (Waters, Milford, MA) and a Q Exactive mass spectrometer (Thermo Scientific) as reported previously (Forde et al., 2015; Song et al., 2017a). Fraction 1 was injected into the trap column (20 mm × 100; Polymicro, Phoenix, AZ) packed with an Aqua C18 column ( $5 \mu \mathrm{m}, 125 \AA$; Phenomenex, Torrance, $\mathrm{CA}$ ) and separated on a micro-analytical column $(50 \mu \mathrm{m} \times 10 \mathrm{~cm}$; Polymicro) packed with an Aqua C18 column ( $3 \mu \mathrm{m}, 125 \AA$; Phenomenex). The eluting program included solvent A ( $0.1 \%$ formic acid in water) and solvent B ( $0.1 \%$ formic acid in acetonitrile); the linear gradient was 1 to $40 \%$ solvent B for $40 \mathrm{~min}$. The flow rate was $0.2 \mu \mathrm{L} / \mathrm{min}$. The eluate was injected directly into the MS system, and electrospray ionization mode was carried out with full mass spectrum scanning at 100 to $2500 \mathrm{~m} / \mathrm{z}$. All identified peptide sequences of goat milk casein hydrolysates were confirmed by comparing them with Capra hircus milk casein from the UniProt (http://www.uniprot.org/) and National Center for Biotechnology Information (http://www .ncbi.nlm.nih.gov) databases.

\section{Statistical Analysis}

All data are expressed as mean \pm standard deviation. Data were analyzed using 1-way ANOVA followed by the Tukey-Kramer post hoc test using SPSS (version 20.0; IBM Inc., Chicago, IL). Differences were considered significant at $P<0.05$. 


\section{RESULTS}

\section{Effects of Goat Milk Casein Hydrolysates on Glucose Consumption Rate}

Compared with controls (normal cells), the glucose consumption rate was significantly decreased in insulinresistant HepG2 cells $(P<0.05)$. However, goat milk casein hydrolysates dramatically increased the glucose consumption rate in insulin-resistant HepG2 cells $(P<$ $0.05)$. The 3 -h hydrolysate showed the highest glucose consumption rate. We observed no difference in cellular glucose consumption rate in insulin-resistant HepG2 cells with or without supplementation of native goat milk casein. The DH increased gradually with longer hydrolysis periods. After $3 \mathrm{~h}$ of hydrolysis, goat milk casein hydrolysates with $23.57 \pm 0.84 \% \mathrm{DH}$ exhibited the highest glucose consumption in insulin-resistant HepG2 cells (Figure 1). Therefore, we used the 3-h goat milk casein hydrolysates for further analysis.

\section{Effects of Goat Milk Casein Hydrolysates on Intracellular Glycogen Concentration}

Goat milk casein hydrolysates $(0.25,0.50$, and 1.00 $\mathrm{mg} / \mathrm{mL}$ ) did not affect cell viability in MEM that contained normal glucose $(5.5 \mathrm{mM})$ or high glucose (30 $\mathrm{m} M$; Figures 2A and 2B). Compared with the control group, high glucose treatment $(30 \mathrm{mM})$ decreased intracellular glycogen concentrations markedly $(P<$ 0.05 ), suggesting that glycogenesis was impaired. However, treatment of HepG2 cells with $1.0 \mathrm{mg} / \mathrm{mL}$ goat milk casein hydrolysates evoked a significant increase in intracellular glycogen concentration in insulin-resistant

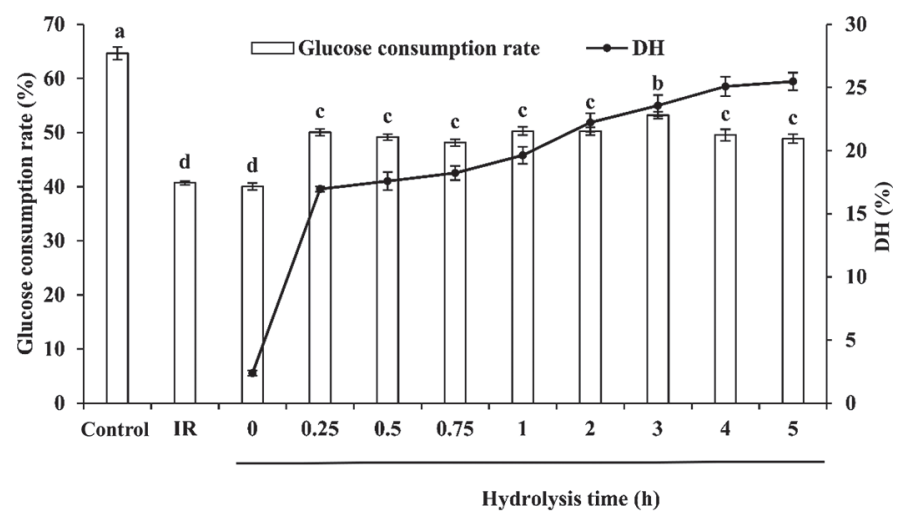

Figure 1. Degree of hydrolysis of goat milk casein hydrolysates and their effects on glucose consumption rate in insulin-resistant HepG2 cells. Values are expressed as means \pm SD of 3 independent determinations. Different letters $(\mathrm{a}-\mathrm{d})$ indicate significant differences $(P<0.05)$. $\mathrm{IR}=$ insulin resistance; $\mathrm{DH}=$ degree of hydrolysis.
A

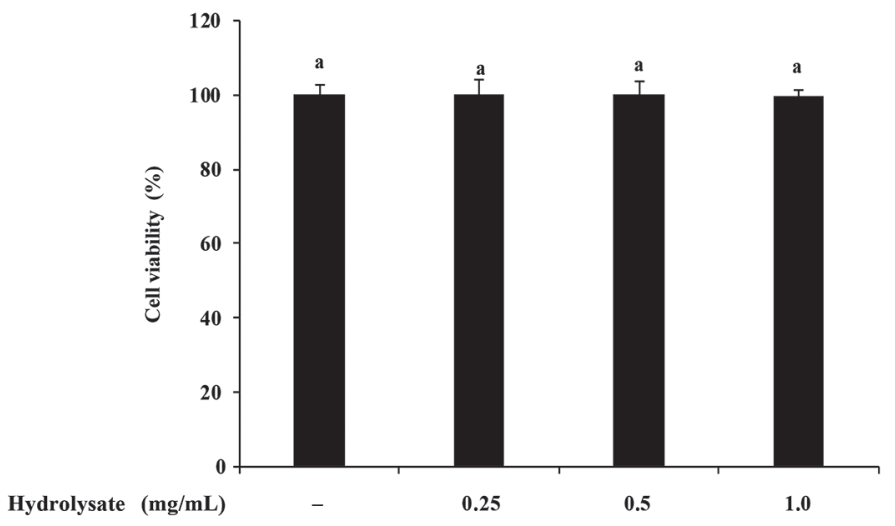

B
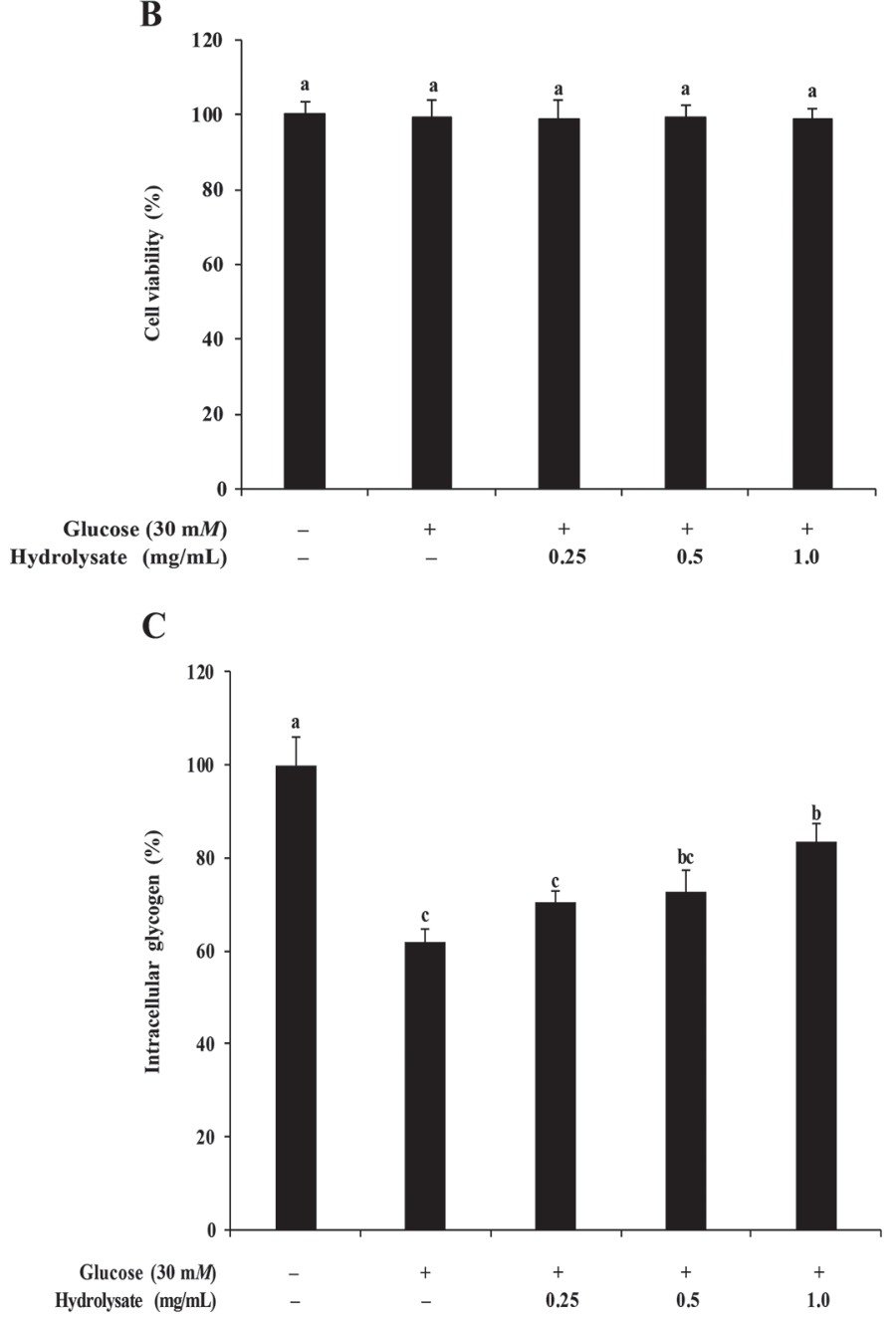

Figure 2. (A) Effects of different concentrations of hydrolysates on cell viability. (B) Effects of different concentrations of hydrolysates in the presence of $30 \mathrm{~m} M$ glucose on cell viability. (C) Effects of goat milk casein hydrolysates on intracellular glycogen content in insulin-resistant HepG2 cells. Values are expressed as means \pm SD of 3 independent determinations. Different letters $(\mathrm{a}-\mathrm{c})$ indicate significant differences $(P<0.05)$. 
HepG2 cells $(P<0.05)$, indicating that goat milk casein hydrolysates promoted glycogenesis (Figure 2C).

\section{Effects of Goat Milk Casein Hydrolysates on mRNA Expression of PCK1 and G6PC}

To define whether goat milk casein hydrolysates had an effect on the mRNA expression of key enzymes in gluconeogenesis in insulin-resistant HepG2 cells, we assayed the expression of $P C K 1$ and $G 6 P C$ using reversetranscription quantitative PCR. High glucose treatment $(30 \mathrm{mM})$ elevated the mRNA expression levels of PCK1 and $G 6 P C$ in gluconeogenesis $(P<0.05)$ compared with the control group. However, goat milk casein hydrolysates reduced the mRNA expression of $P C K 1$ and G6PC markedly in insulin-resistant HepG2 cells $(P<$ 0.05; Figure 3). These results suggest that goat milk casein hydrolysates were helpful in ameliorating insulin resistance through the inhibition of gluconeogenesis. The concentration and quality (absorbance at 260 and $280 \mathrm{~nm}, \mathrm{~A} 260 / \mathrm{A} 280)$ of the RNA and PCR efficiencies are shown in Supplemental Tables S1 and S2, respectively (https://doi.org/10.3168/jds.2019-17513).

\section{Purification and Identification of Peptides that Ameliorated Insulin Resistance}

We separated the bioactive goat milk casein hydrolysates using gel filtration chromatography. We obtained the elution profiles of fractions F1, F2, and F3 from goat milk casein hydrolysates with Sephadex G-25 gel filtration chromatography (Figure 4A).

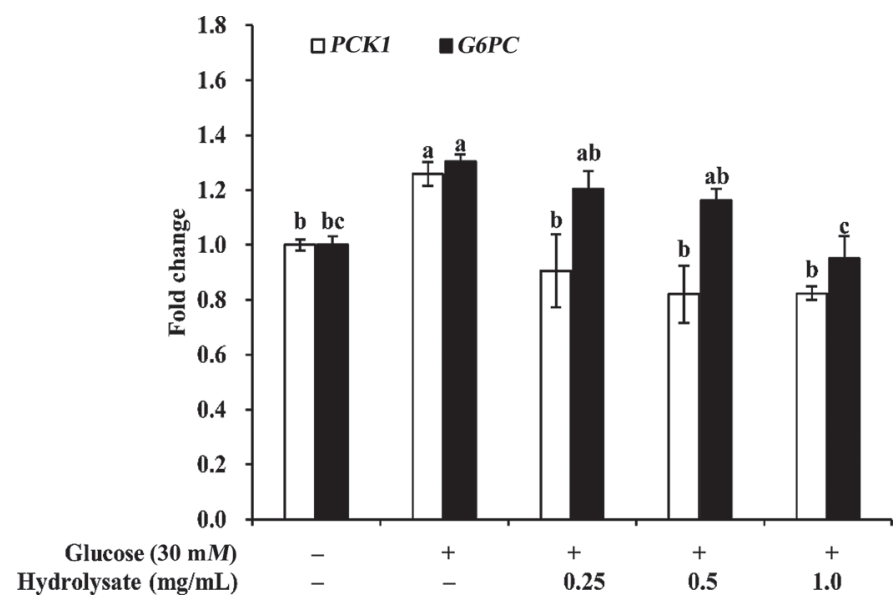

Figure 3. Effects of goat milk casein hydrolysates on mRNA expression of PCK1 and G6PC in insulin-resistant HepG2 cells. Values are expressed as means $\pm \mathrm{SD}$ of 3 independent determinations. Different letters $(\mathrm{a}-\mathrm{c})$ indicate significant differences $(P<0.05) . P C K 1=$ phosphoenolpyruvate carboxykinase 1; $G 6 P C=$ glucose-6-phosphatase catalytic subunit.
A
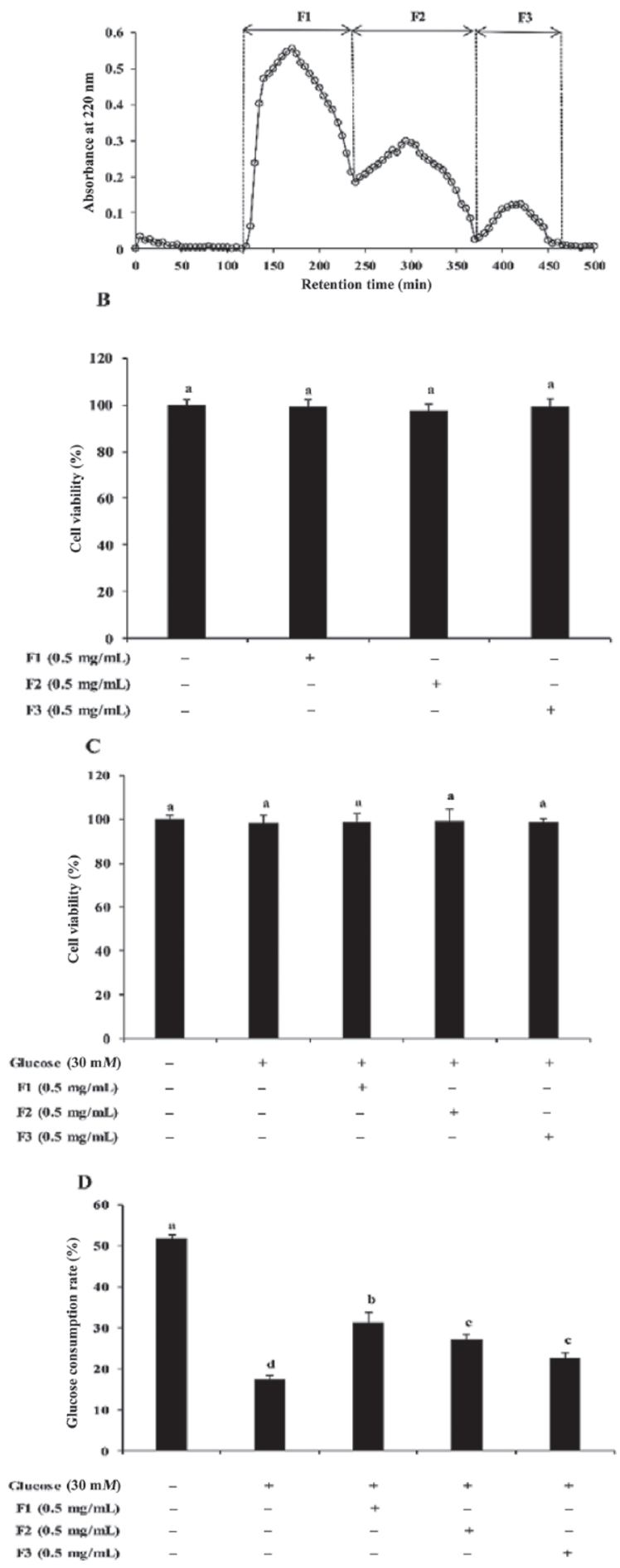

Figure 4. (A) Elution profile of goat milk casein hydrolysates fractions obtained by gel filtration chromatography. (B) Effect of 0.50 $\mathrm{mg} / \mathrm{mL}$ hydrolysate fractions (F1, F2, and F3) on cell viability. (C) Effect of $0.50 \mathrm{mg} / \mathrm{mL}$ hydrolysate fractions (F1, F2, and F3) in the presence of $30 \mathrm{~m} M$ glucose on cell viability. (D) Effects of associated fractions on glucose consumption rate in insulin-resistant HepG2 cells. Values are expressed as means $\pm \mathrm{SD}$ of 3 independent determinations. Different letters $(\mathrm{a}-\mathrm{d})$ indicate significant differences $(P<0.05)$. F1 $=$ fraction $1 ; \mathrm{F} 2=$ fraction $2 ; \mathrm{F} 3=$ fraction 3. 
These fractions did not affect cell viability in HepG2 cells in MEM that contained normal glucose $(5.5 \mathrm{mM})$ or high glucose $(30 \mathrm{~m} M$; Figures $4 \mathrm{~B}$ and $4 \mathrm{C})$. The 3 fractions markedly increased glucose consumption in insulin-resistant HepG2 cells $(P<0.05$; Figure 4D). Compared with F2 and F3, F1 exhibited the highest glucose consumption rate in insulin-resistant HepG2 cells. Therefore, we analyzed F1 further using reversedphase HPLC (Supplemental Figure S1; https://doi .org/10.3168/jds.2019-17513).

\section{Peptide Sequencing Analysis by LC-MS/MS}

To determine the AA composition and sequences of the purified peptides, we evaluated F1 using LC-MS/MS. The LC-MS/MS spectrum of double-charged ions with $m / z$ at 514.75 was matched to sequence SDIPNPIGSE (Figure 5A), and the LC-MS/MS spectrum of triplecharged ions with $m / z$ at 348.19 was matched to sequence NPWDQVKR (Figure 5B). The LC-MS/MS spectrum of double-charged ions with $\mathrm{m} / z$ at 588.77 was matched to sequence SLSSSEESITH (Figure 5C), and the LC-MS/MS spectrum of double-charged ions with $m / z$ at 696.89 was matched to sequence QEPVLGPVRGPFP (Figure 5D). These peptide sequences from goat casein hydrolysate fractions are underlined in Figure 6, where the mature amino acid sequences of goat $\alpha_{\mathrm{S}^{-}} \mathrm{CN}, \alpha_{\mathrm{S}^{2}} \mathrm{CN}$, and $\beta-\mathrm{CN}(\mathrm{C})$ are shown. We also identified the bioactive peptides in F1 using LC-MS/ MS obtained by Sephadex G-25 gel filtration chromatography and reversed-phase HPLC (Table 1).

\section{DISCUSSION}

The liver is an important target organ for insulin action: it maintains systemic glucose homeostasis with a balance between glycogenesis (glucose storage) and gluconeogenesis (glucose output). Insulin resistance in the liver is characterized by insensitivity to insulin, resulting in hyperglycemia and hyperinsulinemia. We used HepG2 cells derived from human hepatocytes to investigate insulin resistance and type 2 diabetes in vitro. A classic insulin-resistant HepG2 cell model is generally used to investigate the pathogenesis of insulin resistance and evaluate the hypoglycemic effects of food-derived bioactive substances in in vitro experiments (Boonloh et al., 2015). We successfully established an insulin-resistant cell model that was exposed to high glucose $(30 \mathrm{mM})$ as described in a previous study (Song et al., 2017b). In the present work, goat milk casein hydrolysates enhanced glucose utilization and ameliorated insulin resistance in insulin-resistant HepG2 cells in vitro. We found that goat milk casein hydrolysates increased glucose consumption rate and intracellular glycogen concentration significantly, but decreased the mRNA expression of PCK1 and G6PC. These findings indicated that specific bioactive peptides derived from goat milk casein contributed to alleviating insulin resistance.

Under insulin-resistant conditions, the synthesis of glycogen is suppressed, leading to an increase in hepatic glucose output and gluconeogenesis (Yan et al., 2016). Gluconeogenesis, a reverse pathway of glycolysis, synthesizes free glucose from non-carbohydrate carbon to maintain blood glucose levels during starvation or vigorous exercise (Wang and Dong, 2019). In people with type 2 diabetes, gluconeogenesis is increased excessively and needs to be inhibited (van Deursen et al., 2008). Phosphoenolpyruvate carboxykinase 1 (PCK1) and glucose-6-phosphatase catalytic subunit ( $G 6 P C)$ are key enzymes that regulate gluconeogenesis. Various studies have proven that decreasing mRNA expression of $P C K 1$ ameliorated both hyperglycemia and insulin resistance, demonstrating that inhibition of gluconeogenesis is a therapeutic target for the treatment of insulin resistance and is potentially useful for treating type 2 diabetes (Gómez-Valadés et al., 2006). To date, various milk-derived peptides have been shown to exhibit antidiabetic activity in cell models (Newsholme et al., 2006). In insulin-resistant HepG2 cells, the peptide IPPKKNQDKTE identified from casein glycomacropeptide hydrolysates showed an increasing effect on glucose consumption and intracellular glycogen concentration in a dose-dependent manner (Song et al., 2017b). In the present study, compared with the high glucose group, the suppression of mRNA expression of G6PC and $P C K 1$ in insulin-resistant HepG2 cells by goat milk casein hydrolysates was 34.75 and $27.16 \%$, respectively. Our previous study showed that the casein-glycomacropeptide-derived peptide IPPKKNQDKTE decreased mRNA expression of $G 6 P C$ and PCK1 by 36.06 and $73.97 \%$, respectively (Song et al., 2017b).

In the present study, we purified 4 peptides that ameliorated insulin resistance from goat milk casein hydrolysates: SDIPNPIGSE $\left(\alpha_{\mathrm{S}_{1}} \mathrm{CN}, \quad \mathrm{f195}-204\right)$, NPWDQVKR $\left(\alpha_{\mathrm{S}^{2}} \mathrm{CN}, \mathrm{f123-130}\right)$, SLSSSEESITH $(\beta-\mathrm{CN}, \mathrm{f} 30-40)$, and QEPVLGPVRGPFP $(\beta-\mathrm{CN}$, f207-219). Peptide sequences that contain Gly and Pro play an important role in improving insulin sensitivity (Lyapina et al., 2013; Malinin et al., 2014). Consistent with these results, in the present study SDIPNPIGSE from $\alpha_{S_{1}-} \mathrm{CN}$ hydrolysates and QEPVLGPVRGPFP from $\beta$-CN hydrolysates contained Gly and Pro, which could ameliorate insulin resistance. As well, DPP4 is a potential binding site for the AA sequence of antidiabetic peptides, which could improve insulin sensitiv- 
A

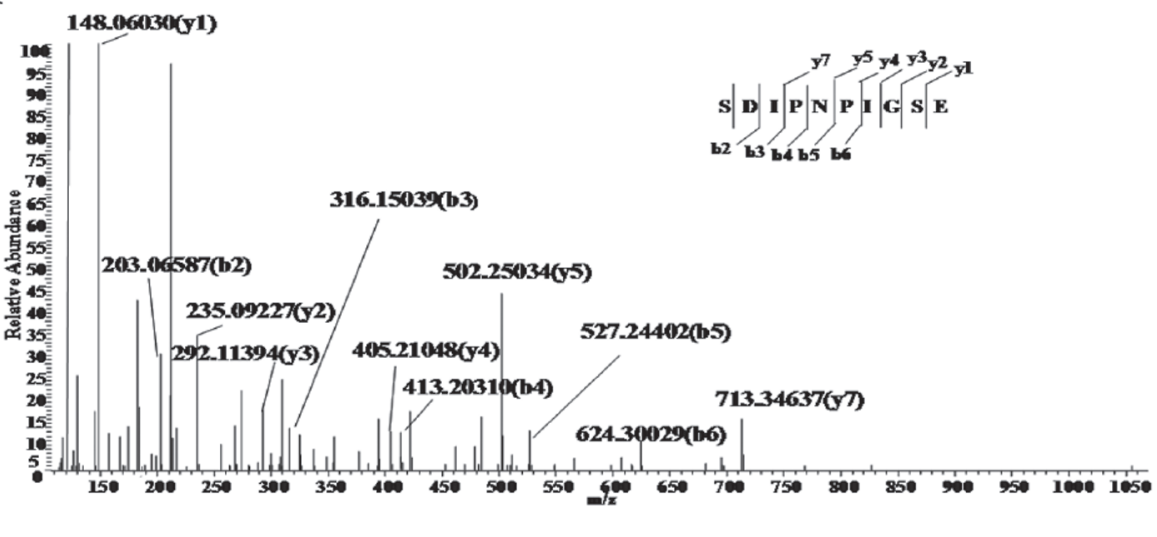

B

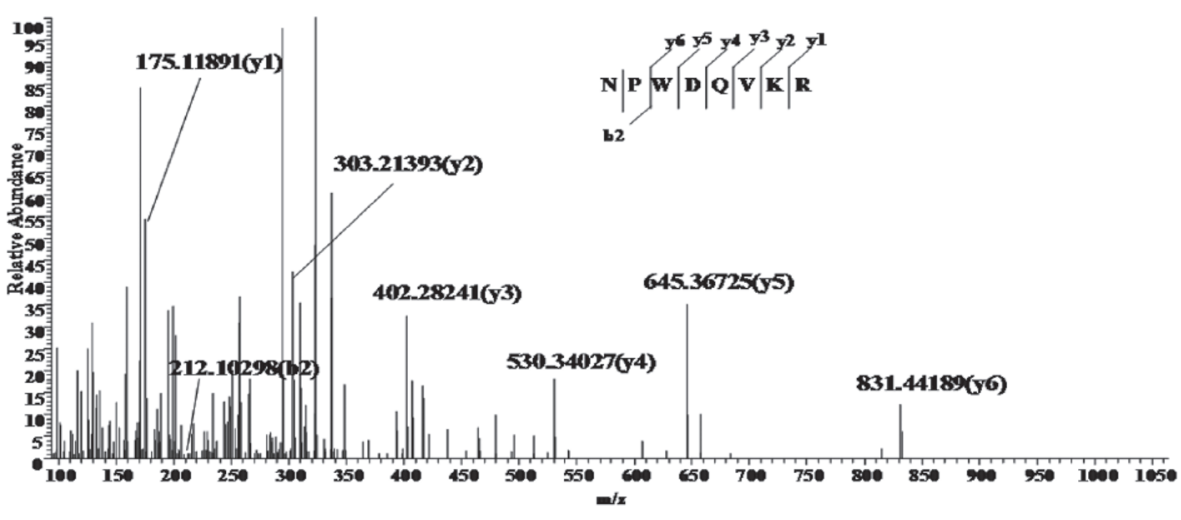

C

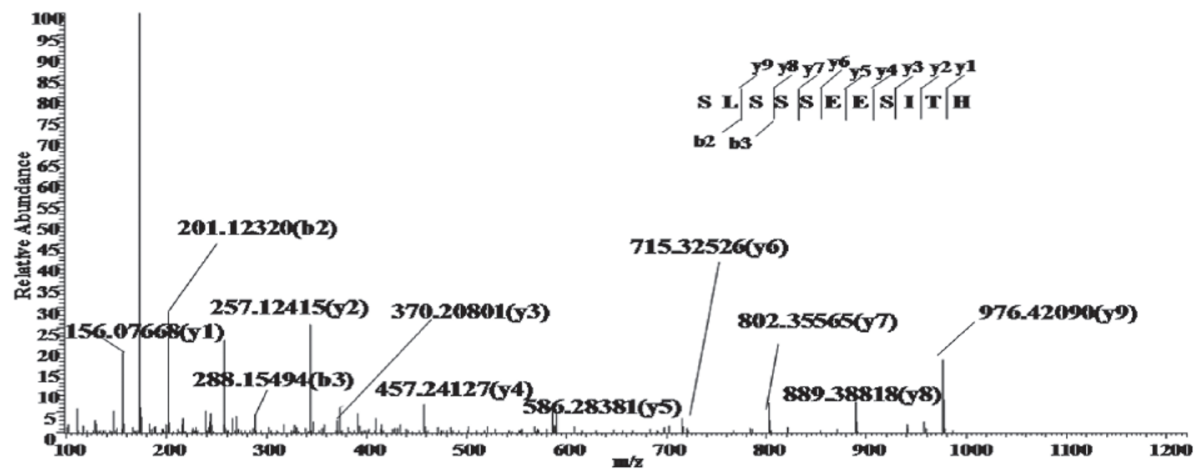

D

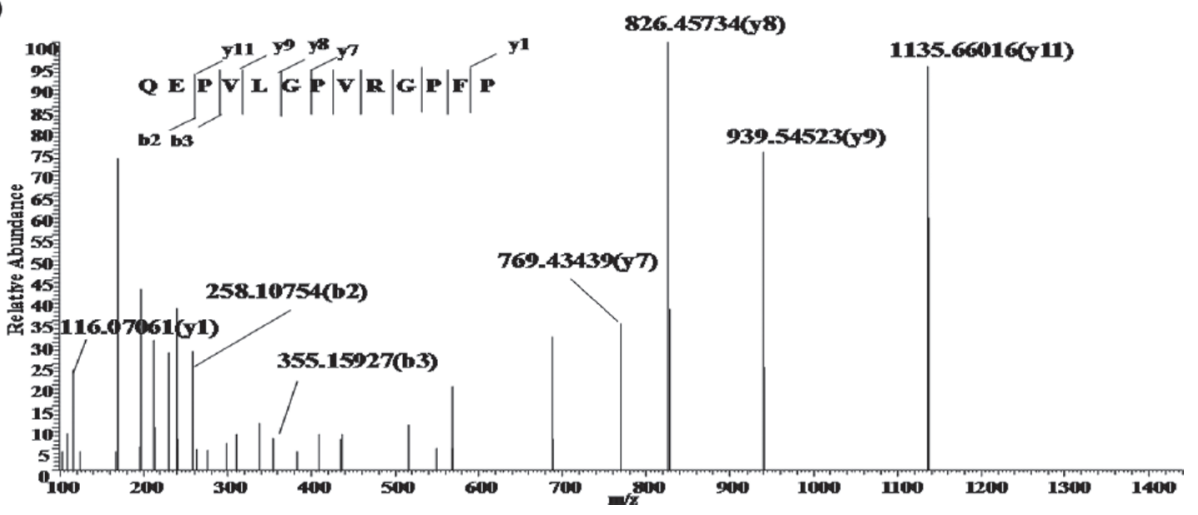

Figure 5. Purification and identification of peptides with the effect of ameliorating insulin resistance. Liquid chromatography-tandem mass spectrometry spectra of peptides (A) SDIPNPIGSE, (B) NPWDQVKR, (C) SLSSSEESITH, and (D) QEPVLGPVRGPFP. 
$\mathbf{A}$
10
20
30
40
50

MKLLILTCLVAVALARPKHPINHRGLSPEVPNENLLRFVVAPFPEVFRKENINEL

$\begin{array}{lrrrrr}60 & 70 & 80 & 90 & 100 & 110\end{array}$

SKDIGSESTEDQAMEDAKQMKAGSSSSSEEIVPNSAEQKYIQKEDVPSERYLGYL

$\begin{array}{rrrr}120 & 130 & 140 & 150\end{array}$

EQLLRLKKYNVPQLEIVPKSAEEQLHSMKEGNPAHQKQPMIAVNQELAYFYPQ

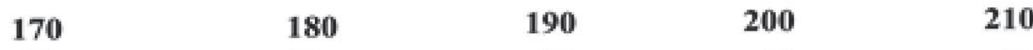

LFRQFYQLDAYPSGAWYYLPLGTQYTDAPSFSDIPNPIGSENSGKTTMPLW

B

$\begin{array}{llllr}10 & 20 & 30 & 40 & 50\end{array}$

MKFFIFTCLLAVALAKHKMEHVSSSEEPINIFQEIYKQEKNMAIHPRKEKLCTTS

$\begin{array}{rrrrrr}60 & 70 & 80 & 90 & 100 & 110\end{array}$

CEEVVRNANEEEYSIRSSSEESAEVAPEEIKITVDDKHYQKALNEINQFYQKFPQY

$\begin{array}{lllll}120 & 130 & 140 & 150 & 160\end{array}$

LQYPYQGPIVLNPWDOVKRNAGPFTPTVNREQLSTSEENSKKTIDMESTEVFTK

$\begin{array}{lrrrr}170 & 180 & 190 & 200 & 210\end{array}$

KTKLTEEEKNRLNFLKKISQYYQKFAWPQYLKTVDQHQKAMKPWTQPKTNAI

220

PYVRYL

C
10
20
30
40
50

MKVLILACLVALAIAREQEELNVVGETVESLSSSEESITHINKKIEKFQSEEQQQT

$\begin{array}{llllll}60 & 70 & 80 & 90 & 100 & 110\end{array}$

EDELQDKIHPFAQAQSLVYPFTGPIPNSLPQNILPLTQTPVVVPPFLQPEIMGVPK

$\begin{array}{rrrrr}120 & 130 & 140 & 150 & 160\end{array}$

VKETMVPKHKEMPFPKYPVEPFTESQSLTLTDVEKLHLPLPLVQSWMHQPPQP

$\begin{array}{llllll}170 & 180 & 190 & 200 & 210 & 220\end{array}$

LSPTVMFPPQSVLSLSQPKVLPVPQKAVPQRDMPIQAFLLYOEPVLGPVRGPFPI

$\mathbf{L V}$

Figure 6. Mature AA sequences of goat (A) $\alpha_{\mathrm{S1}^{-}} \mathrm{CN}$, (B) $\alpha_{\mathrm{S2}^{-}} \mathrm{CN}$, and (C) $\beta$-CN. Peptide sequences identified in goat milk casein hydrolysate fractions are underlined. 
Table 1. Liquid chromatography-tandem mass spectrometry identification of bioactive peptides in fraction 1 obtained from goat milk casein hydrolysates by gel filtration chromatography and reversed-phase HPLC

\begin{tabular}{|c|c|c|c|}
\hline Sequence & $\begin{array}{l}\text { Calculated } \\
\text { mass (Da) }\end{array}$ & $\begin{array}{c}\text { Observed molecular ion, } \\
m / z \text { (charge) }\end{array}$ & Origin \\
\hline \multicolumn{4}{|l|}{$\alpha_{\mathrm{S}^{-}-\mathrm{CN}}$} \\
\hline SDIPNPIGSE & $1,028.07$ & $514.75(2) / 1,028.50(1)$ & $\alpha_{\mathrm{S}_{1}}-\mathrm{CN}, \mathrm{f} 195-204$ \\
\hline \multicolumn{4}{|l|}{$\alpha_{\mathrm{S}^{2}} \mathrm{CN}$} \\
\hline NPWDQVKR & $1,042.15$ & $348.19(3) / 1,042.55(1)$ & $\alpha_{\mathrm{S} 2}-\mathrm{CN}, \mathrm{f} 123-130$ \\
\hline \multicolumn{4}{|l|}{$\beta-\mathrm{CN}$} \\
\hline SLSSSEESITH & $1,176.19$ & $588.77(2) / 1,176.54(1)$ & $\beta-\mathrm{CN}, \mathrm{f} 30-40$ \\
\hline QEPVLGPVRGPFP & $1,392.60$ & $696.89(2) / 1,392.77(1)$ & $\beta-\mathrm{CN}, \mathrm{f} 207-219$ \\
\hline
\end{tabular}

ity (Nongonierma and Fitzgerald, 2013). Such DPP4 inhibitory peptides consist of hydrophobic AA that include Tyr, Trp, Val, Met, Ile, Leu, and Phe (Zhang et al., 2015). Among identified peptides in the present study, SDIPNPIGSE from $\alpha_{S^{-}} \mathrm{CN}$ hydrolysates contained the hydrophobic AA Ile, and NPWDQVKR from $\alpha_{S_{2}} \mathrm{CN}$ hydrolysates contained hydrophobic AA Val and Trp. Furthermore, Ile, Leu, and Val were in the sequences of SLSSSEESITH and QEPVLGPVRGPFP, derived from goat $\beta$-CN hydrolysates. The sequences of Ser-Leu, Ile-Pro, and Phe-Pro also have DPP4 inhibitory activity (Patil et al., 2015). When Pro exists at the $\mathrm{N}$-terminal or C-terminal residue, especially at the second, third, or fourth $\mathrm{N}$-terminal residue, the peptide has potential DPP4 inhibitory activity (Lacroix and Li-Chan, 2014; Nongonierma and Fitzgerald, 2014; Harnedy et al., 2015). In agreement with these reports, the peptides identified in the present study contained Ser-Leu, Ile-Pro, or Phe-Pro residues, indicating that they could ameliorate insulin resistance. The peptides NPWDQVKR and QEPVLGPVRGPFP from the present study had Pro at the second or third N-terminal residue, and SDIPNPIGSE from $\alpha_{\mathrm{S1}^{-}} \mathrm{CN}$ hydrolysates had Pro at the fourth N-terminal residue. These 4 peptides identified from goat milk hydrolysates showed the potential to ameliorate insulin resistance in HepG2 cells.

\section{CONCLUSIONS}

Goat milk casein hydrolysates showed significant improvement in glucose metabolism by increasing glucose consumption rate and intracellular glycogen concentration and decreasing the mRNA expression of $P C K 1$ and $G 6 P C$. We obtained 4 novel peptides that ameliorated insulin resistance: SDIPNPIGSE $\left(\alpha_{S_{1}}-\mathrm{CN}\right.$, f195-204), NPWDQVKR ( $\left.\alpha_{S_{2}-} \mathrm{CN}, \mathrm{f} 123-130\right)$, SLSSSEESITH ( $\beta-C N$, f30-40), and QEPVLGPVRGPFP $(\beta-\mathrm{CN}$, f207-219). Our findings suggest that goat milk casein hydrolysates possess the potential to ameliorate insulin resistance and manage type 2 diabetes. Studies in animal models are recommended.

\section{ACKNOWLEDGMENTS}

This work was supported by the National Natural Science Foundation of China (Beijing, China; grant no. 31871806), National Key Research and Development Program of China (Beijing; 2019YFC1605000), and the Beijing Dairy Industry Innovation Team (BAIC062020). We also thank Thomas A. Gavin, Professor Emeritus, Cornell University (Ithaca, NY) for helping us edit this paper. The authors have not stated any conflicts of interest.

\section{REFERENCES}

Atanasova, J., and I. Ivanova. 2010. Antibacterial peptides from goat and sheep milk proteins. Biotechnol. Biotechnol. Equip. 24:17991803. https://doi.org/10.2478/V10133-010-0049-8.

Bao, L., X. Fu, M. Si, Y. Wang, R. Ma, X. Ren, and H. Lv. 2015. MicroRNA-185 targets SOCS3 to inhibit beta-cell dysfunction in diabetes. PLoS One 10:e0116067. https://doi.org/10.1371/journal .pone.0116067.

Boonloh, K., U. Kukongviriyapan, P. Pannangpetch, B. Kongyingyoes, L. Senggunprai, A. Prawan, S. Thawornchinsombut, and V. Kukongviriyapan. 2015. Rice bran protein hydrolysates prevented interleukin-6-and high glucose-induced insulin resistance in HepG2 cells. Food Funct. 6:566-573. https://doi.org/10.1039/ $\mathrm{C} 4 \mathrm{FO} 00872 \mathrm{C}$

Carver, J. D. 2003. Advances in nutritional modifications of infant formulas. Am. J. Clin. Nutr. 77:1550S-1554S. https://doi.org/10 .1093/ajcn/77.6.1550S.

Chen, J., W. Duan, X. Ren, C. Wang, Z. Pan, X. Diao, and Q. Shen. 2017. Effect of foxtail millet protein hydrolysates on lowering blood pressure in spontaneously hypertensive rats. Eur. J. Nutr. 56:2129-2138. https://doi.org/10.1007/s00394-016-1252-7.

Chen, Y., S. Wang, S.-T. Tian, X. Hu, J. Xu, G.-Z. Yang, and C.Y. Wang. 2016. 12b-hydroxy-des-D-garcigerin A enhances glucose metabolism in insulin-resistant HepG2 cells via the IRS-1/PI3-K/ Akt cell signaling pathway. J. Asian Nat. Prod. Res. 18:1091-1100. https://doi.org/10.1080/10286020.2016.1193489.

Cheng, F., L. Han, Y. Xiao, C. Pan, Y. Li, X. Ge, Y. Zhang, S. Yan, and M. Wang. 2019. D-chiro-Inositol ameliorates high fat dietinduced hepatic steatosis and insulin resistance via $\mathrm{PKC} \varepsilon-\mathrm{PI} 3 \mathrm{~K} /$ AKT pathway. J. Agric. Food Chem. 67:5957-5967. https://doi .org/10.1021/acs.jafc.9b01253.

Cordero-Herrera, I., M. Á. Martín, L. Goya, and S. Ramos. 2014. Cocoa flavonoids attenuate high glucose-induced insulin signalling blockade and modulate glucose uptake and production in human HepG2 cells. Food Chem. Toxicol. 64:10-19. https://doi.org/10 .1016/j.fct.2013.11.014.

Dujic, T., A. Causevic, T. Bego, M. Malenica, Z. Velija-Asimi, E. R. Pearson, and S. Semiz. 2016. Organic cation transporter 1 variants and gastrointestinal side effects of metformin in patients with 
Type 2 diabetes. Diabet. Med. 33:511-514. https://doi.org/10 $1111 /$ dme.13040.

Espejo-Carpio, F. J., C. De Gobba, A. Guadix, E. M. Guadix, and J. Otte. 2013. Angiotensin I-converting enzyme inhibitory activity of enzymatic hydrolysates of goat milk protein fractions. Int. Dairy J. 32:175-183. https://doi.org/10.1016/j.idairyj.2013.04.002.

Forde, N., F. W. Bazer, T. E. Spencer, and P. Lonergan. 2015. 'Conceptualizing' the endometrium: Identification of conceptus-derived proteins during early pregnancy in cattle1. Biol. Reprod. 92:156. https://doi.org/10.1095/biolreprod.115.129296.

Gao, J., J. Song, M. Du, and X. Mao. 2019. Bovine $\alpha$-lactalbumin hydrolysates $(\alpha-\mathrm{LAH})$ attenuate high-fat diet induced nonalcoholic fatty liver disease by modulating hepatic lipid metabolism in C57BL/6J mice. J. Funct. Foods 54:254-262. https://doi.org/10 $.1016 /$ j.jff.2019.01.027.

Gómez-Valadés, A. G., A. Vidal-Alabró, M. Molas, J. Boada, J. Bermúdez, R. Bartrons, and J. C. Perales. 2006. Overcoming diabetesinduced hyperglycemia through inhibition of hepatic phosphoenolpyruvate carboxykinase (GTP) with RNAi. Mol. Ther. 13:401410. https://doi.org/10.1016/j.ymthe.2005.08.026.

Gowd, V., T. Bao, L. Wang, Y. Huang, S. Chen, X. Zheng, S. Cui, and W. Chen. 2018. Antioxidant and antidiabetic activity of blackberry after gastrointestinal digestion and human gut microbiota fermentation. Food Chem. 269:618-627. https://doi.org/10.1016/j .foodchem.2018.07.020.

Gressent, F., P. Da Silva, V. Eyraud, L. Karaki, and C. Royer. 2011. Pea albumin 1 subunit b (PA1b), a promising bioinsecticide of plant origin. Toxins (Basel) 3:1502-1517. https://doi.org/10.3390/ toxins 3121502 .

Haenlein, G. F. W. 2004. Goat milk in human nutrition. Small Rumin. Res. 51:155-163. https://doi.org/10.1016/j.smallrumres.2003 .08 .010 .

Harnedy, P. A., M. B. O'Keeffe, and R. J. Fitzgerald. 2015. Purification and identification of dipeptidyl peptidase (DPP) IV inhibitory peptides from the macroalga Palmaria palmata. Food Chem. 172:400-406. https://doi.org/10.1016/j.foodchem.2014.09.083.

Inglingstad, R. A., T. G. Devold, E. K. Eriksen, H. Holm, M. Jacobsen, K. H. Liland, E. O. Rukke, and G. E. Vegarud. 2010. Comparison of the digestion of caseins and whey proteins in equine, bovine, caprine and human milks by human gastrointestinal enzymes. Dairy Sci. Technol. 90:549-563. https://doi.org/10.1051/ dst $/ 2010018$.

Jafar, S., H. Kamal, P. Mudgil, H. M. Hassan, and S. Maqsood. 2018. Camel whey protein hydrolysates displayed enhanced cholesteryl esterase and lipase inhibitory, anti-hypertensive and anti-haemolytic properties. LWT 98:212-218. https://doi.org/10.1016/j.lwt .2018.08.024

Juillerat-Jeanneret, L. 2014. Dipeptidyl peptidase IV and its inhibitors: Therapeutics for type 2 diabetes and what else? J. Med. Chem. 57:2197-2212. https://doi.org/10.1021/jm400658e.

Kim, D. K., Y. H. Kim, D. Hynx, Y. Wang, K. J. Yang, D. Ryu, K. S. Kim, E. K. Yoo, J. S. Kim, S. H. Koo, I. K. Lee, H. Z. Chae, J. Park, C. H. Lee, S. B. Biddinger, B. A. Hemmings, and H. S. Choi. 2014. PKB/Akt phosphorylation of ERR $\gamma$ contributes to insulin-mediated inhibition of hepatic gluconeogenesis. Diabetologia 57:2576-2585. https://doi.org/10.1007/s00125-014-3366-x.

Kim, W., and J. M. Egan. 2008. The role of incretins in glucose homeostasis and diabetes treatment. Pharmacol. Rev. 60:470-512. https://doi.org/10.1124/pr.108.000604.

Kubota, N., T. Kubota, E. Kajiwara, T. Iwamura, H. Kumagai, T. Watanabe, M. Inoue, I. Takamoto, T. Sasako, K. Kumagai, M. Kohjima, M. Nakamuta, M. Moroi, K. Sugi, T. Noda, Y. Terauchi, K. Ueki, and T. Kadowaki. 2016. Differential hepatic distribution of insulin receptor substrates causes selective insulin resistance in diabetes and obesity. Nat. Commun. 7:12977. https://doi.org/10 .1038/ncomms12977.

Kume, H., K. Okazaki, T. Takahashi, and T. Yamaji. 2014. Protective effect of an immune-modulating diet comprising whey peptides and fermented milk products on indomethacin-induced small-bowel disorders in rats. Clin. Nutr. 33:1140-1146. https://doi.org/10 .1016/j.clnu.2013.12.014.
Lacroix, I. M. E., and E. C. Y. Li-Chan. 2014. Isolation and characterization of peptides with dipeptidyl peptidase-IV inhibitory activity from pepsin-treated bovine whey proteins. Peptides 54:39-48. https://doi.org/10.1016/j.peptides.2014.01.002.

Li, F., F. Yang, X. Liu, L. Wang, B. Chen, L. Li, and M. Wang. 2017a. Cucurbitane glycosides from the fruit of Siraitia grosvenori and their effects on glucose uptake in human HepG2 cells in vitro. Food Chem. 228:567-573. https://doi.org/10.1016/j.foodchem .2017.02.018.

Li, T., B. Chen, M. Du, J. Song, X. Cheng, X. Wang, and X. Mao. 2017b. Casein glycomacropeptide hydrolysates exert cytoprotective effect against cellular oxidative stress by up-regulating HO-1 expression in HepG2 cells. Nutrients 9:31. https://doi.org/10 $.3390 /$ nu9010031.

Li, Z., A. Jiang, T. Yue, J. Wang, Y. Wang, and J. Su. 2013. Purification and identification of five novel antioxidant peptides from goat milk casein hydrolysates. J. Dairy Sci. 96:4242-4251. https://doi .org/10.3168/jds.2012-6511.

Lyapina, L. A., N. F. Myasoedov, M. E. Grigor'eva, T. A. Shubina, and L. A. Andreeva. 2013. The modern concept of the regulatory role of peptides of the glyproline family in the correction of hemostasis system function during development of diabetes mellitus. Biol. Bull. 40:386-393. https://doi.org/10.1134/S1062359013040109.

Ma, J., X. Mao, Q. Wang, S. Yang, D. Zhang, S. Chen, and Y.-H. Li. 2014. Effect of spray drying and freeze drying on the immunomodulatory activity, bitter taste and hygroscopicity of hydrolysate derived from whey protein concentrate. Lebensm. Wiss. Technol. 56:296-302. https://doi.org/10.1016/j.lwt.2013.12.019.

Malinin, V. V., T. N. Savateeva-Lyubimova, and K. V. Sivak. 2014. Hypolipidemic and hypoglycemic effect of peptide Lys-Glu-TrpNH2 in rats with associated metabolic disorders. Bull. Exp. Biol. Med. 156:338-341. https://doi.org/10.1007/s10517-014-2344-0.

Matboli, M., A. Shafei, M. Ali, K. M. Kamal, M. Noah, P. Lewis, A. Habashy, M. Ehab, A. I. Gaber, and H. Abdelzaher. 2018. Emerging role of nutrition and the non-coding landscape in type 2 diabetes mellitus: A review of literature. Gene 675:54-61. https://doi .org/10.1016/j.gene.2018.06.082.

Meng, R., D. Zhu, Y. Bi, D. Yang, and Y. Wang. 2013. Erythropoietin inhibits gluconeogenesis and inflammation in the liver and improves glucose intolerance in high-fat diet-fed mice. PLoS One 8:e53557. https://doi.org/10.1371/journal.pone.0053557.

Milburn, M. V., and K. A. Lawton. 2013. Application of metabolomics to diagnosis of insulin resistance. Annu. Rev. Med. 64:291-305. https://doi.org/10.1146/annurev-med-061511-134747.

Newsholme, P., L. Brennan, and K. Bender. 2006. Amino acid metabolism, $\beta$-cell function, and diabetes. Diabetes 55(Suppl. 2):S39-S47. https://doi.org/10.2337/db06-S006.

Nimalaratne, C., N. Bandara, and J. Wu. 2015. Purification and characterization of antioxidant peptides from enzymatically hydrolyzed chicken egg white. Food Chem. 188:467-472. https://doi.org/10 .1016/j.foodchem.2015.05.014.

Nocito, L., A. S. Kleckner, E. J. Yoo, A. R. Jones IV, M. Liesa, and B. E. Corkey. 2015. The extracellular redox state modulates mitochondrial function, gluconeogenesis, and glycogen synthesis in murine hepatocytes. PLoS One 10:e0122818. https://doi.org/10 .1371/journal.pone.0122818.

Nongonierma, A. B., and R. J. Fitzgerald. 2013. Dipeptidyl peptidase IV inhibitory and antioxidative properties of milk protein-derived dipeptides and hydrolysates. Peptides 39:157-163. https://doi .org/10.1016/j.peptides.2012.11.016.

Nongonierma, A. B., and R. J. Fitzgerald. 2014. An in silico model to predict the potential of dietary proteins as sources of dipeptidyl peptidase IV (DPP-IV) inhibitory peptides. Food Chem. 165:489498. https://doi.org/10.1016/j.foodchem.2014.05.090.

Nongonierma, A. B., S. Paolella, P. Mudgil, S. Maqsood, and R. J. FitzGerald. 2017. Dipeptidyl peptidase IV (DPP-IV) inhibitory properties of camel milk protein hydrolysates generated with trypsin. J. Funct. Foods 34:49-58. https://doi.org/10.1016/j.jff.2017 .04 .016 .

Parsamanesh, N., M. Moossavi, A. Bahrami, A. E. Butler, and A. Sahebkar. 2018. Therapeutic potential of curcumin in diabetic com- 
plications. Pharmacol. Res. 136:181-193. https://doi.org/10.1016/ j.phrs.2018.09.012.

Patil, P., S. Mandal, S. K. Tomar, and S. Anand. 2015. Food proteinderived bioactive peptides in management of type 2 diabetes. Eur. J. Nutr. 54:863-880. https://doi.org/10.1007/s00394-015-0974-2.

Pfaffl, M. W. 2001. A new mathematical model for relative quantification in real-time RT-PCR. Nucleic Acids Res. 29:e45. https://doi .org/10.1093/nar/29.9.e45.

Ren, Z., Z. Xie, D. Cao, M. Gong, L. Yang, Z. Zhou, and Y. Ou. 2018. C-Phycocyanin inhibits hepatic gluconeogenesis and increases glycogen synthesis: Via activating Akt and AMPK in insulin resistance hepatocytes. Food Funct. 9:2829-2839. https://doi.org/10 .1039/C8FO00257F.

Rungapamestry, V., J. Mcmonagle, C. Reynolds, G. Rucklidge, M. Reid, G. Duncan, K. Ross, G. Horgan, S. Toomey, A. P. Moloney, B. de Roos, and H. M. Roche. 2012. Inter-organ proteomic analysis reveals insights into the molecular mechanisms underlying the anti-diabetic effects of cis-9, trans-11-conjugated linoleic acid in ob/ob mice. Proteomics 12:461-476. https://doi.org/10.1002/pmic .201100312 .

Samarakoon, K. W., K. O-Nam, J.-Y. Ko, J.-H. Lee, M.-C. Kang, D. Kim, J. B. Lee, J.-S. Lee, and Y.-J. Jeon. 2013. Purification and identification of novel angiotensin-I converting enzyme (ACE) inhibitory peptides from cultured marine microalgae (Nannochloropsis oculata) protein hydrolysate. J. Appl. Phycol. 25:1595-1606. https://doi.org/10.1007/s10811-013-9994-6.

Sharabi, K., C. D. J. Tavares, A. K. Rines, and P. Puigserver. 2015. Molecular pathophysiology of hepatic glucose production. Mol. Aspects Med. 46:21-33. https://doi.org/10.1016/j.mam.2015.09.003.

Song, J. J., Q. Wang, M. Du, X. M. Ji, and X. Y. Mao. 2017a. Identification of dipeptidyl peptidase-IV inhibitory peptides from mare whey protein hydrolysates. J. Dairy Sci. 100:6885-6894. https:// doi.org/10.3168/jds.2016-11828.

Song, J. J., Q. Wang, M. Du, T. G. Li, B. Chen, and X. Y. Mao. 2017b. Casein glycomacropeptide-derived peptide IPPKKNQDKTE ameliorates high glucose-induced insulin resistance in HepG2 cells via activation of AMPK signaling. Mol. Nutr. Food Res. 61:112. https://doi.org/10.1002/mnfr.201600301.

Uenishi, H., T. Kabuki, Y. Seto, A. Serizawa, and H. Nakajima. 2012. Isolation and identification of casein-derived dipeptidyl-peptidase 4 (DPP-4)-inhibitory peptide LPQNIPPL from gouda-type cheese and its effect on plasma glucose in rats. Int. Dairy J. 22:24-30. https://doi.org/10.1016/j.idairyj.2011.08.002.

van Deursen, D., H. Jansen, and A. J. M. Verhoeven. 2008. Glucose increases hepatic lipase expression in HepG2 liver cells through upregulation of upstream stimulatory factors 1 and 2. Diabetologia 51:2078-2087. https://doi.org/10.1007/s00125-008-1125-6.

Wang, J., K. Du, L. Fang, C. Liu, W. Min, and J. Liu. 2018. Evaluation of the antidiabetic activity of hydrolyzed peptides derived from Juglans mandshurica Maxim. fruits in insulin-resistant HepG2 cells and type 2 diabetic mice. J. Food Biochem. 42:e12518. https://doi .org $/ 10.1111 /$ jfbc. 12518 .

Wang, Z., and C. Dong. 2019. Gluconeogenesis in cancer: Function and regulation of PEPCK, FBPase, and G6Pase. Trends Cancer 5:30-45. https://doi.org/10.1016/j.trecan.2018.11.003.

Yamaguchi, K., T. Nishimura, H. Ishiba, Y. Seko, A. Okajima, H. Fujii, N. Tochiki, A. Umemura, M. Moriguchi, Y. Sumida, H. Mitsuyoshi, K. Yasui, M. Minami, T. Okanoue, and Y. Itoh. 2015. Blockade of interleukin 6 signalling ameliorates systemic insulin resistance through upregulation of glucose uptake in skeletal muscle and improves hepatic steatosis in high-fat diet fed mice. Liver Int. 35:550-561. https://doi.org/10.1111/liv.12645.

Yan, F., G. Dai, and X. Zheng. 2016. Mulberry anthocyanin extract ameliorates insulin resistance by regulating PI3K/AKT pathway in HepG2 cells and db/db mice. J. Nutr. Biochem. 36:68-80. https: //doi.org/10.1016/j.jnutbio.2016.07.004.

Zanutto-Elgui, M. R., J. C. S. Vieira, D. Z. do Prado, M. A. R. Buzalaf, P. M. Padilha, D. Elgui de Oliveira, and L. F. Fleuri. 2019 Production of milk peptides with antimicrobial and antioxidant properties through fungal proteases. Food Chem. 278:823-831. https://doi.org/10.1016/j.foodchem.2018.11.119.

Zhang, Q., J. Ren, M. Zhao, H. Zhao, J. M. Regenstein, Y. Li, and J. Wu. 2011. Isolation and characterization of three novel peptides from casein hydrolysates that stimulate the growth of mixed cultures of Streptococcus thermophilus and Lactobacillus delbrueckii ssp. bulgaricus. J. Agric. Food Chem. 59:7045-7053. https://doi .org/10.1021/jf200903u.

Zhang, Y., R. Chen, H. Ma, and S. Chen. 2015. Isolation and identification of dipeptidyl peptidase IV-inhibitory peptides from trypsin/chymotrypsin-treated goat milk casein hydrolysates by $2 \mathrm{D}$ TLC and LC-MS/MS. J. Agric. Food Chem. 63:8819-8828. https: //doi.org/10.1021/acs.jafc.5b03062. 